\title{
Correction to: Endophytic colonization of tomato plants by the entomopathogenic fungus Beauveria bassiana for controlling the South American tomato pinworm, Tuta absoluta
}

Ana Carolina Loreti Silva, Gerson Adriano Silva, Pedro Henrique Nogueira Abib, Aline Teixeira Carolino and Richard lan Samuels ${ }^{*}$ (i)

\section{Correction to: CABI Agric Biosci (2020) 1:3}

https://doi.org/10.1186/s43170-020-00002-x

Following publication of the original article (Silva et al. 2020), the authors identified an error in the author name of Ana Carolina Loreti Silva.

- The incorrect author name is: Ana Carolina Lorete Silva.

- The correct author name is: Ana Carolina Loreti Silva.

The author group has been updated above and the original article (Silva et al. 2020) has been corrected.

\section{Reference}

Silva ACL, Silva GA, Abib PHN, Carlino AT, Samuels RI. Endophytic colonization of tomato plants by the entomopathogenic fungus Beauveria bassiana for controlling the South American tomato pinworm, Tuta absoluta. CABI Agric Biosci. 2020;1:3. https://doi.org/10.1186/s43170-020-00002-x.

Published online: 18 July 2020

The original article can be found online at https://doi.org/10.1186/s4317 0-020-00002-x.

*Correspondence: richardiansamuels@gmail.com

Laboratório de Entomologia e Fitopatologia, Universidade Estadual

do Norte Fluminense Darcy Ribeiro, Av. Alberto Lamego 2000, Campos

dos Goytacazes, RJ 28013-602, Brazil

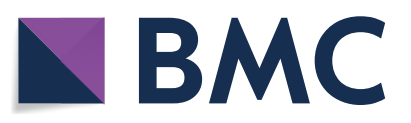

(c) The Author(s) 2020. This article is licensed under a Creative Commons Attribution 4.0 International License, which permits use, sharing, adaptation, distribution and reproduction in any medium or format, as long as you give appropriate credit to the original author(s) and the source, provide a link to the Creative Commons licence, and indicate if changes were made. The images or other third party material in this article are included in the article's Creative Commons licence, unless indicated otherwise in a credit line to the material. If material is not included in the article's Creative Commons licence and your intended use is not permitted by statutory regulation or exceeds the permitted use, you will need to obtain permission directly from the copyright holder. To view a copy of this licence, visit http://creativecommons.org/licenses/by/4.0/. The Creative Commons Public Domain Dedication waiver (http://creativecommons.org/publicdomain/zero/1.0/) applies to the data made available in this article, unless otherwise stated in a credit line to the data. 